\title{
ANTIMICROBIAL POTENTIALS OF SILVER COLLOIDAL (NANORODS) ON CLINICAL ISOLATES IN BAYELSA STATE, NIGERIA
}

\author{
${ }^{1}$ Tatfeng Y. Mirabeau, ${ }^{2}$ Ojo T. O., and ${ }^{3}$ Simon M. Agwale \\ ${ }^{1,2}$ Department of Medical Laboratory Science, Niger Delta University, Bayelsa State, Nigeria \\ ${ }^{3}$ Clinical Virology Laboratory, Innovative Biotech, Keffi/Abuja, Nigeria. \\ *E-mail: youtchou@yahoo.com
}

\begin{abstract}
Absract
Antimicrobial resistance in developing countries has long been an issue of major concern. Nanotechnology has become an eye opener for the intervention on multiple drug resistance organisms. In this study we investigated the antimicrobial potentials of Silver Nitrate (nanorods) solution used in managing infectious diseases, the Minimum Inhibitory Concentration (MIC) and Minimum Bactericidal Concentration (MBC) of the product against microbial isolates were determined using standard microbiological techniques. The mean MIC and MBC of silver nitrate solution on fungi $(0.16$ $\mu \mathrm{g} / \mathrm{ml}$ and $0.29 \mu \mathrm{g} / \mathrm{ml}$ respectively) was significantly lower than that of Gram positive organisms $(2.35 \mu \mathrm{g} / \mathrm{ml} \mathrm{and} 2.62 \mu \mathrm{g} / \mathrm{ml})$ and Gram negative organisms $(2.05 \mu \mathrm{g} / \mathrm{ml}$ and $2.10 \mu \mathrm{g} / \mathrm{ml})$. Of all the Gram positive organisms, Staphylococcus spp recorded the lowest mean MICand MBC while in the Gram negative organisms group, E. coli isolates showed the lowest mean MIC and $\mathrm{MBC}$ of the silver nitrate solution, though not significantly different from the other isolates. In conclusion, results from this study revealed that Silver Nitrate(nanorods) may have be broad spectrum in activity, but with higher antifungal potentials.
\end{abstract}

Key Words: Antimicrobial, silver colloidal, clinical isolates, Bayelsa.

\section{Introduction}

Antimicrobial resistance is an increasing problem in the practice of infectious disease.The emergence and spread of antibiotic resistance is also an alarming concern in clinical practice (Coloumbus, 1998). Nanotechnology, a new technology of impregnation of silver nanoparticles is enabling a wider range of medical products to be available to clinicians (Furno et al., 2004). Silver nanoparticles are being coated on materials and medical devices as prophylaxis to prevent bacteria from growing or for therapeutic use (Darouiche, 1999). The use of metallic silver has long been recognised, medical uses of silver includes incorporation into wound dressing, to treat external infections, used as antiseptic disinfectant in medical appliances such as urinary catheters, endotracheal breathing tubes where the silver content is effective in reducing incidences of urinary tract infections and ventilator-associated pneumoniae (VAP) (Saint et al., 1998).

Dilute solutions of silver nitrate had been used to treat infections and burns before the introduction of silver sulphadiazine cream (Fox, 1998). Silver nitrate is a broad spectrum agent, bacteriostatic at a concentration of $0.5 \%$ is effective in prophylactic use in second and third degree burns,development of resistance to silver ion is distinctly uncommon (Moyer et al., 1965). Silver and silver compounds have an oligodynamic effect and are toxic to bacteria, algae and fungi in vitro, among heavy metals that have this effect, silver is least toxic to humans and the antibacterial actions is independent on the silver ion (Lansdown, 2006).

\section{Materials and methods Study design}

This study was carried out in Niger Delta University, Bayelsa state, clinical isolates obtained from clinical specimens obtained from medical laboratories in the state. The silver nitrate solution or silver colloidal was obtained from Innovative Biotech. Laboratory, Keffi/Abuja.

\section{Microbial Isolation and Identification}

Sixty nine (69) isolates comprising of 19 fungi, 27 Gram positive and 23 Gram negative bacteria were used in this study. The isolation of microbes was done culturally using Mac conkey, blood agar,mannitol salt agar, nutrient agar and sarboraud dextrose agar, microbial identification was carried out using standard bacteriological techniques which include Gram staining of the isolates, Biochemical testing i.e Coagulase, Catalase, Citrate utilization, Indole production,oxidase test,Sugar fermentation tests, Germ tube test.

\section{Minimum inhibitory concentration (MIC) testing (Tube Dilution Method)}

A pure culture of was grown in Mueller-Hinton broth. The cultures were standardized using standard microbiological techniques to have a concentration of $10^{6}$ cells per milliliter. Dilutions (ten-fold, two-fold and $3 / 4$-fold as the 
case may be) of the silver nitrate nanorods stock were made in Mueller-Hinton broth. After the antimicrobial agent was diluted, a volume of the standardized inoculums equal to the volume of the diluted antimicrobial agent was added to each dilution vessel, bringing the microbial concentration to approximately 500,000 cells per milliliter. The inoculated, serially diluted silver nitrate solution was incubated at $37^{\circ} \mathrm{C}$ for 18 hours. After incubation, the series of dilution vessels were observed for microbial growth, usually indicated by turbidity and/or a pellet of microorganisms in the bottom of the vessel. The concentration in the last tube in the dilution series that did not demonstrate growth corresponded with the minimum inhibitory concentration (MIC) of the Silver nitrate solution.

\section{Minimum Bactericidal Concentration (MBC)}

From the MIC test tubes series where turbidity or sign of microbial growth were not visible, subculture were made onto Mueller-Hinton agar plates noting their respective concentration. The concentration in the last tube series from which subculture did not show growth was recorded as the MBC.

\section{Results}

Of the 69 isolates analyzed, the mean MIC of the silver nanorod was $1.70 \mu \mathrm{g} / \mathrm{ml}, 2.75 \mu \mathrm{g} / \mathrm{ml}$ and $2.62 \mu \mathrm{g} / \mathrm{ml}$ on Staphylococcus sp, Streptococcus spp and Bacillus spp respectively while a MBC of $2.0 \mu \mathrm{g} / \mathrm{ml}, 3.25 \mu \mathrm{g} / \mathrm{ml}$ and $2.62 \mu \mathrm{g} / \mathrm{ml}$ was obtained against the above mentioned organisms respectively. E. coli, Klebsiella pneimoniae, Pseudomonas spp, Proteus spp, and Citrobacter spp were all inhibited at a least mean concentration of $2.0 \mu \mathrm{g} / \mathrm{ml}, 2.50 \mu \mathrm{g} / \mathrm{ml}, 2.15 \mu \mathrm{g} / \mathrm{ml}, 2.62 \mu \mathrm{g} / \mathrm{ml}$, and $1.0 \mu \mathrm{g} / \mathrm{ml}$ respectively. Candida spp were all inhibited at the least mean concentration of $0.16 \mu \mathrm{g} / \mathrm{ml}$. There was no significant difference between the MIC and MBC of the silver nanorods on the various bacterial isolates $(\mathrm{P} \geq 0.05)$ (Table 1). The mean MIC and MBC of the silver nitrate solution on Gram positive, Gram negative and fungal isolates were $2.35 \mu \mathrm{g} / \mathrm{ml}$ and $2.62 \mu \mathrm{g} / \mathrm{ml}, 2.04 \mu \mathrm{g} / \mathrm{ml}$ and $2.10 \mu \mathrm{g} / \mathrm{ml}$, and $0.16 \mu \mathrm{g} / \mathrm{ml}$ and $0.29 \mu \mathrm{g} / \mathrm{ml}$ respectively. The mean MIC and MBC of the silver nitrate solution on fungal isolates were significantly higher than those of Gram positive and Gram negative organisms, $(\mathrm{P} \leq 0.05)$ (Table 2)

Table 1: Mean MIC and MBC of the silver nitrate solution against microbial isolates

\begin{tabular}{|c|c|c|}
\hline ORGANISM & MEAN MIC ( $\mu \mathrm{g} / \mathrm{ml})$ & MEAN MBC $(\mu \mathrm{g} / \mathrm{ml})$ \\
\hline Staphylococcus spp (13) & 1.70 & 2.0 \\
\hline Streptococcus spp (8) & 2.75 & 3.25 \\
\hline Bacillus spp & 2.62 & 2.62 \\
\hline E. coli & 2.0 & 2.0 \\
\hline Kliebsella spp & 2.50 & 2.50 \\
\hline Pseudomonas spp & 2.15 & 2.15 \\
\hline Proteus spp & 2.62 & 2.62 \\
\hline Citrobacter spp & 1.00 & 1.25 \\
\hline Candida spp & 0.16 & 0.29 \\
\hline
\end{tabular}

Table 2: Mean MIC and MBC of silver nitrate solution by cell type

\begin{tabular}{|l|l|l|}
\hline ORGANISM & MEAN MIC $(\mu \mathrm{g} / \mathrm{ml})$ & MEAN MBC $(\mu \mathrm{g} / \mathrm{ml})$ \\
\hline Gram Positive Organisms & 2.35 & 2.62 \\
\hline Gram Negative Organisms & 2.04 & 2.10 \\
\hline Fungi & 0.16 & 0.29 \\
\hline
\end{tabular}

\section{Discussion}

Silver particles over years have been included into many medical preparations. Although usually used on skin and other surfaces, silver nitrate particles are now prepared in form of food supplement which are administered orally to manage a sizeable number of ailments. Findings from this showed that silver nanorods have both antifungal and antibacterial activities as it was found to inhibit growth of Staphylococcus aureus, streptococcus spp, Bacillus spp, E. coli, Klebsiella spp, Proteus spp, Citrobacter spp Pseudomonas spp and Candida spp at very low concentrations. These observations are in line with findings of Atiteh et al., (2007); Qin, (2005); Hermans (2006) who reported that Silver kills bacteria in external wounds in living tissue, so physicians use wound dressings containing silver sulfadiazine (Ag-SD) or silver nanomaterials to treat external infections. Although Staphylococcus spp exhibited the lowest MIC among Gram positive cocci (GPC). E. coli also exhibited the lowest MIC among Gram Negative Bacilli (GNB), this was similar to previous findings reported by Kim et al., 
(2007) and Kenneth et al., (2010). In general, the silver nitrate solution exhibited a significantly higher antifungal activity than antibacterial. This obviously could be due to differences in cellular composition of fungi and bacteria. Kenneth et al., (2010) reported that silver nanorod inhibits DNA function by interracting with protein-rich membrane and could also attack the respiratory chain. Several researchers have reported the side effects of these nanorod products by establishing threshold beyond which they may become toxic or predispose one to cancer, to circumvent their health hazards, they are produced in very small size particles (nanometer) to enable their excretion by the body.

In conclusion, advance in nanotechnology has enabled us to utilize particles in the size of nanoscale, this has created new therapeutic horizons as silver revealed the surface of the potential benefits and the wide range of applications. The most important goal is to increase adherence to basic infection control policies and procedures.

\section{References}

1. Atiteh BS, Costagliola M, Hayek SN, Dibo SA (2007). "Effect of silver on burn wound infection control and healing: review of the literature". Burns 33 (2): 139-48.

2. Columbus C (1998). Baylor Health Care System: Antimicrobial resistance in bacteria pathogens, pp183-185.

3. Darouiche R (1999): Anti-infection efficacy of silver-coated medical prostheses; Clin Infect of Dis; 29:1371-1377.

4. $\quad$ Fox C. (1968): Silver sulphadiazine- a new topical therapy for Pseudomonas in burns. Therapy of Pseudomonas infection in burns Arch surg; 96:184-188.

5. Furno F, Morley K, and Wong B(2004): Silver nanoparticles and polymer medical devices:a new approach to prevention of infection. J Antimicrob Chemother; 54:1019-1024.

6. Hermans MH (2006): Silver-containing dressings and the need for evidence. The American journal of nursing; 106 (12): $60-8$.

7. Kenneth K, Wong C and Xuelai Liu (2010): Silver nanoparticles-the real silver bullet in Clinical Medicine. Med Chem.Commu 7(1): 125-131.

8. Kim J, Kuk E, Kim J, Park S, Lee H, Park Y, Hwang C, Jeong D and Cho M (2007): Antimicrobial Effect of Silver nanoparticles. Nanomedicine; 3(1):95-101.

9. Lansdown, A (2006): Silver in Healthcare: Antimicrobial effects and safety in use. Current problems in Dermatology, 33:17-34.

10. Moyer CA, Brentano 1, Gravens Dl, Margraf HW, Monafo WW (1965): treatment of large human burns with 0.5 per cent silver nitrate solution. Arch Sur;. 90:812-86.

11. Saint N,Lacapere J, Gul Q, Glazi A, Martinac B and Riqau M (1998): A hexameric transmembrane pore revealed by two -dimensional crystallization of the largemechanosensitive ion channel J Biol Chem; 273 (24): 14667-14670 